\title{
Increased angiogenesis is associated with a 32-gene expression signature and 6p21 amplification in aggressive endometrial cancer
}

\author{
Ingunn M. Stefansson ${ }^{1,2, *}$, Maria Raeder ${ }^{1,3, *}$, Elisabeth Wik ${ }^{1,2}$, Monica Mannelqvist ${ }^{1,2}$, \\ Kanthida Kusonmano ${ }^{1,3}$, Gøril Knutsvik ${ }^{1,2}$, Ingfrid Haldorsen ${ }^{4,5}$, Jone Trovik ${ }^{1,3}$, \\ Anne M. Øyan ${ }^{1,6}$, Karl-H. Kalland ${ }^{1,6}$, Anne Cathrine Staff', Helga B. Salvesen ${ }^{1,3}$ and \\ Lars A. Akslen ${ }^{1,2}$ \\ ${ }^{1}$ Centre for Cancer Biomarkers CCBIO, Department of Clinical Medicine, Section for Pathology, University of Bergen, Bergen, \\ Norway \\ 2 Department of Pathology, Haukeland University Hospital, Bergen, Norway \\ ${ }^{3}$ Department of Obstetrics and Gynaecology, Haukeland University Hospital, Bergen, Norway \\ ${ }^{4}$ Department of Radiology, Haukeland University Hospital, Postbox, Bergen, Norway \\ ${ }^{5}$ Section for Radiology, University of Bergen, Bergen, Norway \\ ${ }^{6}$ Department of Microbiology, Haukeland University Hospital, Bergen, Norway \\ ${ }^{7}$ Department of Obstetrics and Gynaecology, Women and Children's Division, Oslo University Hospital, University of Oslo, \\ Norway \\ * These authors contributed equally to this work \\ Correspondence to: Lars A. Akslen, email: lars.akslen@k1.vib.no \\ Keywords: angiogenesis, endometrial cancer, gene expression signature, prognosis \\ Received: January 19, $2015 \quad$ Accepted: February 17, $2015 \quad$ Published: March 10, 2015
}

This is an open-access article distributed under the terms of the Creative Commons Attribution License, which permits unrestricted use, distribution, and reproduction in any medium, provided the original author and source are credited.

\section{ABSTRACT}

Background: Angiogenesis is a hallmark of cancer. The aim of this study was to explore whether microvessel proliferation is associated with gene expression profiles or copy number alterations in endometrial cancer.

Methods: A prospective series of endometrial carcinomas was studied for angiogenesis markers, gene expression profiles, and gene copy number data. For validation, an independent series of endometrial carcinomas as well as an external cohort of endometrial cancer patients were examined by gene expression microarrays.

Results: Increased microvessel proliferation (MVP) was associated with aggressive tumor features and reduced survival, and a 32-gene expression signature was found to separate tumors with high versus low MVP. An increased 32-gene signature score was confirmed to associate with high-grade tumor features and reduced survival by independent cohorts. Copy number studies revealed that amplification of the 6p21 region was significantly associated with MVP, a high 32gene score, as well as reduced survival.

Conclusion: Increased MVP was significantly associated with aggressive endometrial cancer and reduced survival. Integrated analyses demonstrated significant associations between increased vascular proliferation, amplification of the 6p21 region, VEGF-A mRNA expression, and the 32-gene angiogenesis signature. Our findings indicate amplification of $6 \mathrm{p21}$ as a possible driver of tumor vascular proliferation in endometrial cancer. 


\section{INTRODUCTION}

Although the majority of endometrial cancers are curable by surgery and adjuvant treatment, a subset still displays an aggressive clinico-pathologic phenotype characterized by high histologic grade, lympho-vascular and myometrial invasion, and reduced survival [1]. The mechanisms leading to poor-prognosis subgroups of endometrial cancer, and how to target them, are not known in detail. Recent studies have focused on the importance of genetic alterations in tumor cells, as well as the influence of tumor microenvironment factors [2,3].

We previously reported that several mechanisms appear to be activated and co-exist in aggressive endometrial cancer [4-7], among them tumor angiogenesis $[5,8]$. Vascular proliferation, as a novel angiogenesis marker, was associated with features of progressive tumors and impaired prognosis in several cancers [5,911]. Vascular invasion, the presence of tumor cells within vascular channels and a morphologic marker of early metastatic spread, is found more often in tumors with increased angiogenesis and less mature vessels $[4,5]$. We subsequently showed that active angiogenesis and increased invasive properties by epithelial-mesenchymal transition appeared to co-exist and associate with vascular invasion and reduced survival [12]. These mechanisms might represent an important program for tumor-vascular interactions in aggressive endometrial cancer and might further point to directions for targeted treatment of these tumors. Also, multiple genetic alterations in endometrial carcinoma have been published $[13,14]$ but little is known about the relationship between genetic changes and activated tumor angiogenesis. Here, we show by integrated analysis of novel angiogenesis tissue markers, gene expression profiling, gene copy number data, and comprehensive clinico-pathologic characterisation that tumor angiogenesis appear to be associated with co-ordinated transcriptional patterns. Thus, increased vascular proliferation was associated with a 32-gene expression signature as well as amplification of the $6 \mathrm{p} 21$ region harbouring the VEGF-A gene and a corresponding increase in VEGF-A tissue expression. The 32-gene signature was associated with aggressive tumor features and reduced survival, also by independent validation. Our findings suggest a rationale for anti-angiogenesis treatment in endometrial cancers and that high vascular proliferation might represent a potential biomarker predicting response to VEGF inhibition.

\section{RESULTS}

\section{Increased angiogenesis is associated with aggressive endometrial cancer}

Median microvessel proliferation (MVP, absolute proliferation) was $2.72 / \mathrm{mm}^{2}$ (mean 3.03; range $0-11.25$ ). MVP was significantly associated with an aggressive pathologic phenotype, in particular non-endometrioid histologic type, higher histologic grade, vascular invasion, presence of tumor necrosis, and reduced survival (Table 1; Figure 1A). Correspondingly, median vascular proliferation index (VPI) was $4.5 \%$ (mean 5.4\%; range $0-18 \%$ ) in this series. VPI showed similar but slightly weaker associations with histopathologic variables when compared with MVP (Table 1).

The median microvessel density (MVD) (75 cases) was 50 microvessels $/ \mathrm{mm}^{2}$ (mean 53; range 0.7-123). Increased MVD was associated with presence of vascular invasion and deep myometrial invasion, but not with any of the other clinico-pathologic variables (data not shown).

Glomeruloid Microvascular Proliferation (GMP), the formation of vascular nests or bodies [15] and assumed to reflect the presence of VEGF-driven angiogenesis [16], was found in 24 tumors (29\%), and this feature was associated with presence of tumor necrosis $(P=0.019)$ but not with any other clinico-pathologic variables (data not shown).

\section{A 32-gene expression signature reflecting microvessel proliferation is associated with aggressive tumor features and reduced survival}

Genes differentially expressed (cut-off, FDR < $25 \%$ ) between tumors with high versus low microvessel proliferation (MVP), were included in a vascular proliferation signature of 32 genes (Supplementary Table 1). As expected, the identified 32-gene expression score was associated with MVP (Figure 1B), as well as with features of aggressive endometrial cancer, such as nonendometrioid histologic subtype, high histologic grade, high FIGO stage (Supplementary Figure 1A-C) and reduced survival (Figure 1C).

Interestingly, several of the genes up-regulated in the 32-gene signature (e.g TPM1, PDGFB, SERPINH1 and ITGB3) are previously reported to be regulators of vascular proliferation and angiogenesis (Supplementary Table 1); TPM1 is linked to cytoskeleton remodelling critical in angiogenesis [17]; PDGFB is reported to be a potent contributor in angiogenesis by attracting smooth muscle cells as well as VEGF receptors [18]; Colligilin2, the corresponding protein of the gene SERPINH1, has been suggested to take part in neovascularization in gliomas [19]; ITGB3 has been found to take part in 
A

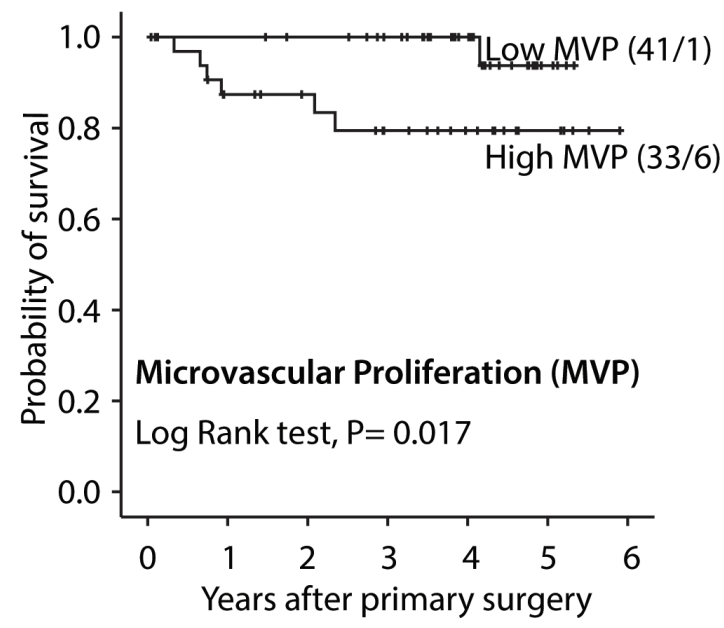

B

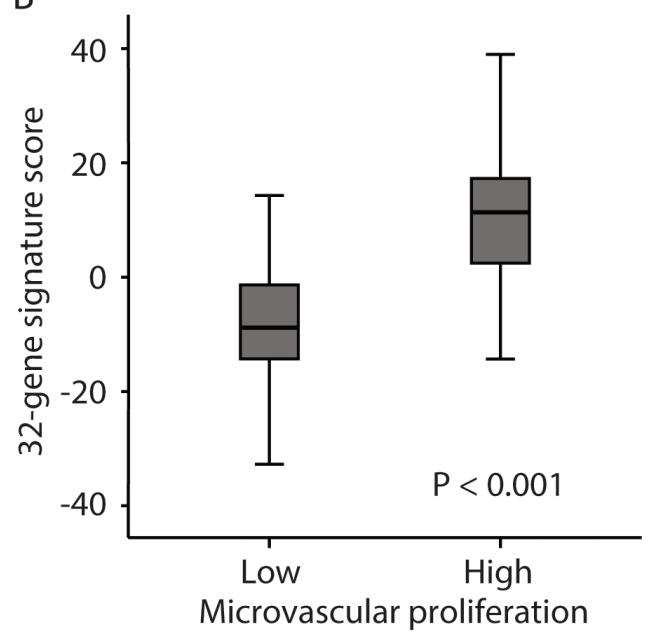

C

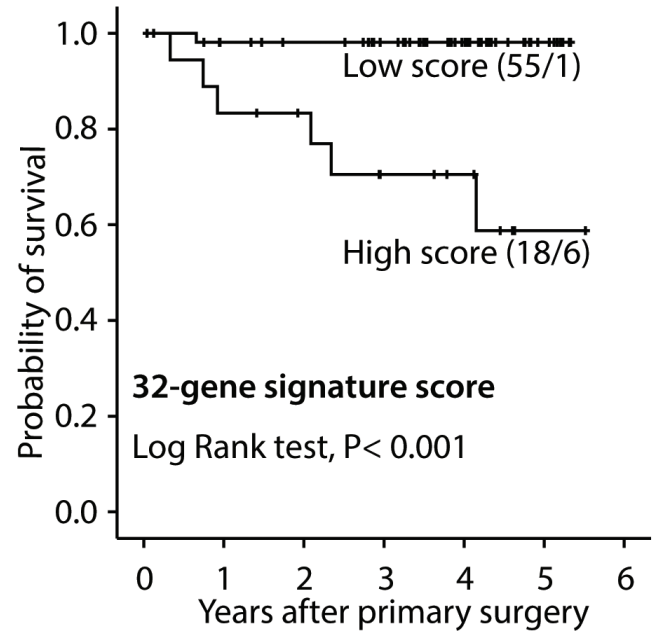

Figure 1: Survival curves by A: high and low microvascular proliferation (MVP), B: high and low vascular proliferation index (VPI) and C: high and low 32-gene signature score. All analyses were done according to the Kaplan-Meier method, (cut-off by median value). Number of cases/number of events in parenthesis.

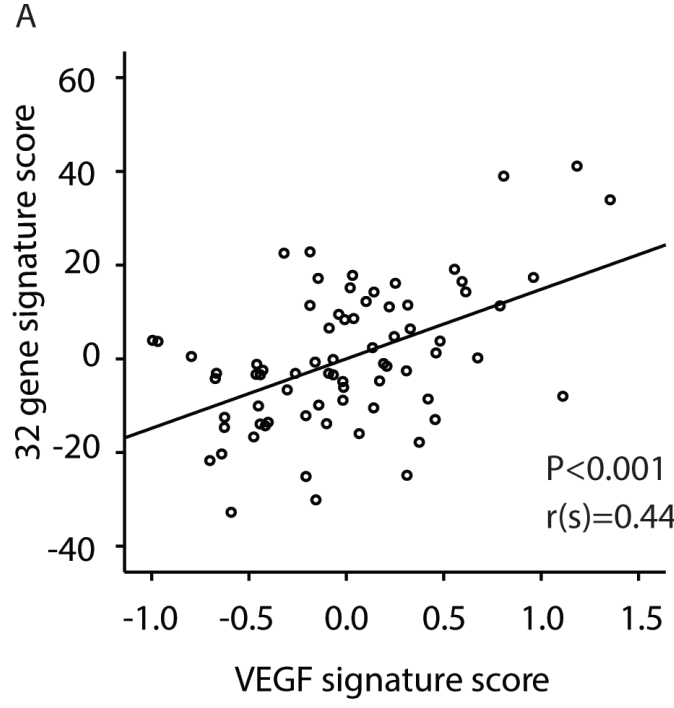

B

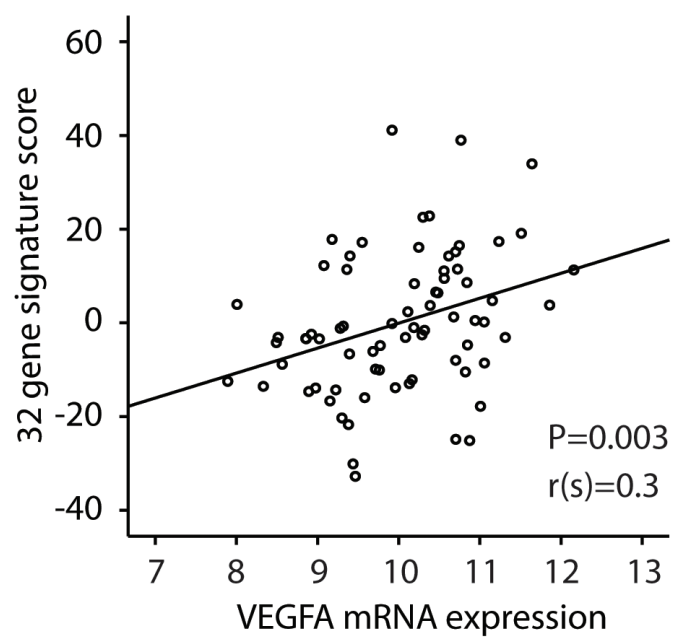

C

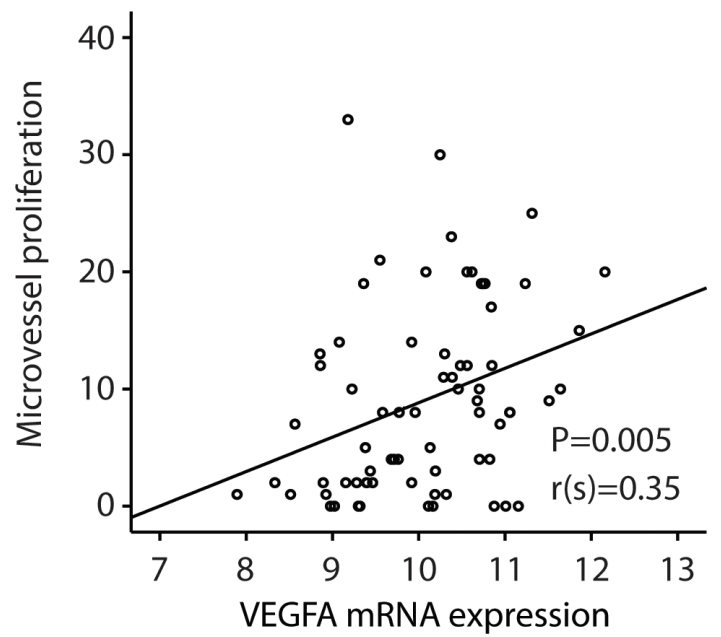

Figure 2: Correlations between: $A$ : the 32-gene signature score and a VEGF-signature [25]; B: the 32gene signature score and VEGF mRNA expression; $\mathrm{C}$ : Correlation between microvessel proliferation (MVP) and VEGF mRNA expression. The Spearman rank correlation test was used for bivariate correlations. 
Table 1: Vascular proliferation (MVP, VPI) in relation to histopathologic features in 77 patients with endometrial carcinoma

\begin{tabular}{|c|c|c|c|c|c|}
\hline Variable & No of patients ${ }^{a}$ & $\begin{array}{c}\text { Absolute } \\
\text { proliferation }^{\text {b }} \\
\text { (MVP) }\end{array}$ & P-value ${ }^{c}$ & $\begin{array}{c}\text { Vascular } \\
\text { Proliferation } \\
\text { Index (VPI) }\end{array}$ & P-value $^{c}$ \\
\hline $\begin{array}{l}\text { Histologic type } \\
\text { Endometrioid } \\
\text { Non-endometrioid }\end{array}$ & $\begin{array}{l}65 \\
10\end{array}$ & $\begin{array}{l}2.4 \\
5.1\end{array}$ & 0.039 & $\begin{array}{l}4.9 \\
8.6\end{array}$ & 0.043 \\
\hline $\begin{array}{c}\text { Histologic grade } \\
\text { Grade } 1 \\
\text { Grade } 2 \\
\text { Grade } 3 \\
\end{array}$ & $\begin{array}{l}16 \\
41 \\
18\end{array}$ & $\begin{array}{c}7.2 \\
7.6 \\
13.2 \\
\end{array}$ & 0.08 & $\begin{array}{l}4.1 \\
5.0 \\
7.3\end{array}$ & 0.034 \\
\hline $\begin{array}{l}\text { Tumour necrosis } \\
\text { Absent } \\
\text { Present }\end{array}$ & $\begin{array}{l}34 \\
41\end{array}$ & $\begin{array}{l}1.3 \\
3.1\end{array}$ & 0.03 & $\begin{array}{l}2,8 \\
6.5\end{array}$ & 0.06 \\
\hline $\begin{array}{l}\text { Mitotic count } \\
\quad \leq 10 \\
\quad>10\end{array}$ & $\begin{array}{l}34 \\
41\end{array}$ & $\begin{array}{l}1.7 \\
3.1\end{array}$ & ns & $\begin{array}{l}4,2 \\
6.4\end{array}$ & 0.04 \\
\hline $\begin{array}{c}\text { Vascular invasion } \\
0 / 1 \text { vessel } \\
>1 \text { vessel } \\
\end{array}$ & $\begin{array}{l}44 \\
31 \\
\end{array}$ & $\begin{array}{l}1,4 \\
3.4\end{array}$ & ns & $\begin{array}{l}3.8 \\
6.5\end{array}$ & 0.06 \\
\hline $\begin{array}{l}\text { Myometrial infiltration } \\
\leq 50 \\
>50\end{array}$ & $\begin{array}{l}34 \\
41 \\
\end{array}$ & $\begin{array}{l}2.7 \\
2.7 \\
\end{array}$ & ns & $\begin{array}{l}5.3 \\
5.5 \\
\end{array}$ & ns \\
\hline $\begin{array}{l}\text { ER } \\
\text { Positive } \\
\text { Negative }\end{array}$ & $\begin{array}{l}54 \\
19 \\
\end{array}$ & $\begin{array}{l}1.8 \\
4.1\end{array}$ & ns & $\begin{array}{l}3.36 \\
6.70\end{array}$ & 0.022 \\
\hline $\begin{array}{l}\text { PR } \\
\text { Positive } \\
\text { Negative }\end{array}$ & $\begin{array}{l}54 \\
19\end{array}$ & $\begin{array}{l}1.8 \\
4.1\end{array}$ & ns & $\begin{array}{l}3.66 \\
6.53\end{array}$ & 0.09 \\
\hline
\end{tabular}

a Total number of patients: 77 ; results available in 75 cases (MVP, VPI) and 73 cases (ER/PR)

${ }^{\mathrm{b}}$ Median value of proliferating vessels pr. $\mathrm{mm}^{2}$; ${ }^{\mathrm{c}}$ Mann-Whitney U test

Abbreviations: $\mathrm{MVP}=$ microvessel proliferation, $\mathrm{VPI}=$ vascular proliferation index, $\mathrm{ER}=$ estrogen reseptor, $\mathrm{PR}=$ progesterone reseptor

Table 2: Association between 6p21 amplification status and measures of vascular proliferation (MPV, VPI)

\begin{tabular}{|c|c|c|c|c|c|}
\hline Variable & No of patients & $\begin{array}{c}\text { Microvascular } \\
\text { a proliferation } \\
\text { (MVP) }\end{array}$ & P-value $^{\sharp}$ & $\begin{array}{l}\text { Vascular } \\
\text { Proliferation }_{\text {Index (VPI) }}^{*}\end{array}$ & P-value $^{\mathrm{b}}$ \\
\hline 6p21 status & & & & & \\
Amplification - & 56 & 7,56 & $<0.0001$ & 4,59 & $<0.0001$ \\
Amplification + & 10 & 18,2 & & 11,07 & \\
\hline
\end{tabular}

Abbreviations: $\mathrm{MVP}=$ microvessel proliferation, $\mathrm{VPI}=$ vascular proliferation index

${ }^{\mathrm{a}}$ Median value of proliferating vessels pr. $\mathrm{mm}^{2}$; ${ }^{b}$ Mann-Whitney $\mathrm{U}$ test

endothelial cell adhesion and migration, as part of angiogenesis induced by FOXC2 [20].

Although with a relatively high FDR $(<55 \%)$ in gene set enrichment analyses (GSEA), gene sets reflecting EGFR/HER2 signaling, TGF $\beta$ response [21] and gene ontology categories of angiogenesis stimulation and cell proliferation were significantly enriched in tumors with high microvascular proliferation (MVP), further supporting that our developed vascular proliferation signature is a highly relevant readout for transcriptional alterations regulating angiogenesis. Furthermore, a signature of endothelial cells from invasive endometrial carcinoma [22] and a gene set of HMGA1 targets [23] were enriched in tumors with high MVP. HMGA1 is previously demonstrated to be involved in angiogenesis and cancer progression and is upregulated in response to hypoxia [24]. 
Table 3: Relationship between 6p21 amplification status and histopathologic features in patients with endometrial carcinoma

\begin{tabular}{|c|c|c|c|}
\hline Variable & No 6p21 ampl & $+6 \mathrm{p} 21$ ampl & P-value \\
\hline $\begin{array}{l}\text { Histologic type } \\
\text { Endometrioid } \\
\text { Non-endometrioid }\end{array}$ & $\begin{array}{r}54(91) \\
4(44)\end{array}$ & $\begin{array}{l}5(9) \\
5(56)\end{array}$ & $<0.0001$ \\
\hline $\begin{array}{c}\text { Histologic grade } \\
\text { Grade } 1 / 2 \\
\text { Grade } 3 \\
\end{array}$ & $\begin{array}{r}49(92) \\
9(60) \\
\end{array}$ & $\begin{array}{l}4(8) \\
6(40) \\
\end{array}$ & 0.002 \\
\hline $\begin{array}{c}\text { Tumour necrosis } \\
\text { Absent } \\
\text { Present }\end{array}$ & $\begin{array}{l}28(93) \\
30(79)\end{array}$ & $\begin{array}{l}2(7) \\
8(21)\end{array}$ & 0.09 \\
\hline $\begin{array}{c}\text { Mitotic count } \\
\leq 10 \\
>10\end{array}$ & $\begin{array}{l}31(100) \\
27(73)\end{array}$ & $\begin{array}{c}0(0) \\
10(27)\end{array}$ & 0.002 \\
\hline $\begin{array}{c}\text { Vascular invasion } \\
0 / 1 \text { vessel } \\
\geq 2 \text { vessel } \\
\end{array}$ & $\begin{array}{l}37(90) \\
21(78)\end{array}$ & $\begin{array}{l}4(10) \\
6(22)\end{array}$ & 0.15 \\
\hline $\begin{array}{c}\text { Myometrial infiltration } \\
<50 \\
\geq 50\end{array}$ & $\begin{array}{l}29(91) \\
29(81)\end{array}$ & $\begin{array}{l}3(9) \\
7(19)\end{array}$ & 0,24 \\
\hline $\begin{array}{c}\text { ER } \\
\text { Positive } \\
\text { Negative }\end{array}$ & $\begin{array}{l}46(94) \\
12(67)\end{array}$ & $\begin{array}{l}4(8) \\
6(33)\end{array}$ & 0.009 \\
\hline $\begin{array}{c}\text { PR } \\
\text { Positive } \\
\text { Negative }\end{array}$ & $\begin{array}{l}48(94) \\
10(59)\end{array}$ & $\begin{array}{l}3(6) \\
7(41)\end{array}$ & $<0.0001$ \\
\hline $\begin{array}{c}\text { FIGO stage } \\
\text { I/II } \\
\text { III } / \text { IV }\end{array}$ & $\begin{array}{c}52(51) \\
6(54)\end{array}$ & $\begin{array}{c}5(9) \\
5(46)\end{array}$ & 0.002 \\
\hline
\end{tabular}

${ }^{\mathrm{c} C h i-s q u a r e}$ test

\section{The 32-gene signature is associated with other prognostic signatures potentially reflecting angiogenesis}

We next examined the correlation between our 32gene score and 6 different gene signatures previously reported to reflect angiogenesis and outcome in a range of cancers: a VEGF signature [25], a vascular invasion signature [26], a wound response signature [27], a hypoxia gene signature [28], a TGF $\beta$ gene-response signature of human epithelial cells [29] and a BMI-1 driven stemness related gene signature [30]. All signatures tended to or were significantly correlated to the present 32 -gene vascular proliferation signature, as shown in Supplementary Table 2. Figure 2 illustrates this significant correlation between the VEGF-A signature and our 32gene score (Spearman's rho correlation $0.44 ; P<0.001$ ), as well as the correlation between VEGF-A mRNA and microvessel proliferation in our series (Figure 2A-C).

\section{Validation of the 32-gene signature score in endometrial cancer}

We then explored the 32-gene signature score in an additional independent series of endometrial carcinoma patients $(n=37)$ previously described [31]. There were no differences regarding histologic type, histologic grade, myometrial infiltration or FIGO stage between this series and our primary investigation series (data not shown). In the validation series, the 32 -gene score was significantly associated with features of aggressive endometrial cancer, such as non-endometrioid histologic type $(P=0.009)$ and high histologic grade $(P=0.012)$. A high 32-gene score was significantly associated with progression/recurrence-free survival (Supplementary Figure 2). Also, a high signature score was significantly associated with reduced tumor blood flow $\left(\mathrm{ml} / 100 \mathrm{ml} \mathrm{min}^{-1}\right.$ ), (both variables categorized by median value), as assessed by functional MRI ( $82 \%$ of tumors with reduced blood flow had high signature score, $18 \%$ had low signature score), $P=0.001$ ).

In the publicly available data set of 111 endometrial carcinomas (NCBI GEO: GSE2109), 23 of the 32 genes in the vascular proliferation signature were found. A high signature score in this data set was significantly associated with non-endometrioid histology, high histologic grade, 
and high FIGO stage (Supplementary Figure 1D-F), as well as low estrogen and progesterone receptor gene expression (both $P<0.001$ ).

\section{Increased 6p21 copy number associates with microvessel proliferation}

In an analysis of clinico-pathologic factors and significant gene amplifications to predict increased microvessel proliferation, amplification of the $6 \mathrm{p} 21$ chromosomal region (present in 10 cases; $15 \%$ ) was by far most significantly associated with vascular proliferation, both microvessel proliferation (MVP) (Figure 3A) and vascular proliferation index (VPI) (Table

A

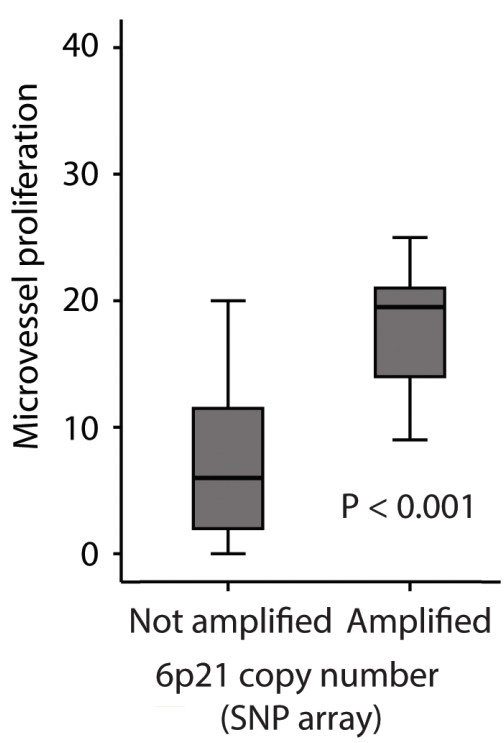

C

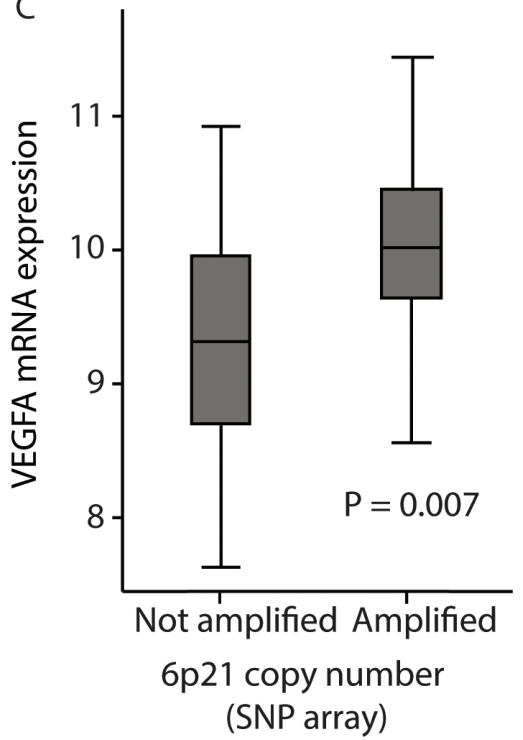

2). Notably, 6p21 amplification was not associated with standard microvessel density (MVD) $(P=0.41)$. The 32gene signature score was significantly elevated in $6 \mathrm{p} 21$ amplified cases, and the amplification was associated with reduced patient survival (Figure 3B and D). The 6p21 amplification was significantly associated with more aggressive histopathologic phenotype, such as histologic type, histologic grade, high mitotic count, loss of ER and PR expression, as well as FIGO stage (Table 3).

The VEGF-A gene is located within the amplified $6 \mathrm{p} 21$ region and was upregulated in tumors with this amplification (Figure 3C). VEGF gene expression itself (mRNA) was also significantly correlated to microvessel proliferation (Spearman's rho Correlation $=0.35, P=0.005$ ) (Figure 2C).

B

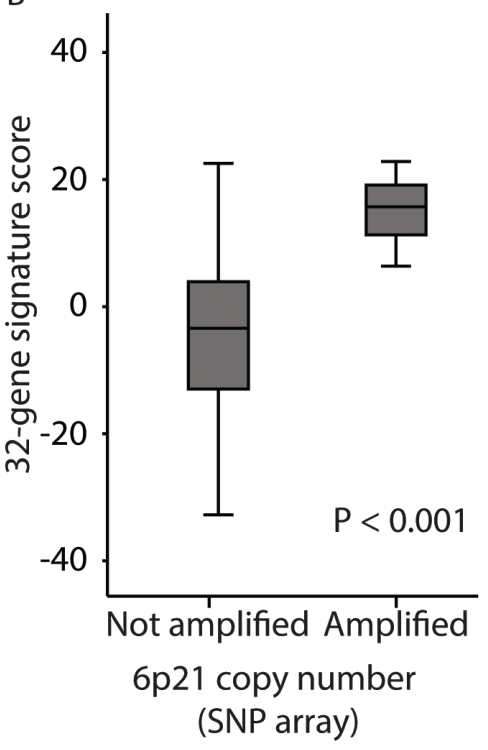

D

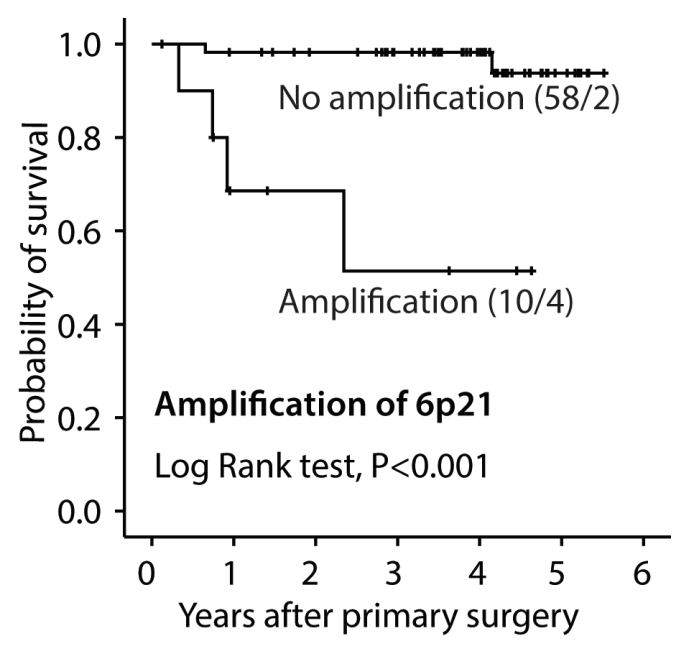

Figure 3: Relation between 6p21 amplification and: A: microvessel proliferation (MVP); B: the 32-gene signature score; C: VEGF mRNA expression, and D: disease specific survival according to the Kaplan-Meier method. Number of cases/number of events in parenthesis. 


\section{Serum markers of angiogenesis}

The serum concentration of several angiogenic factors (VEGF-A, PIGF, GDF-15, sFlt, sEng) were compared to tissue-based angiogenesis markers and clinico-pathologic factors. Myometrial infiltration $>50 \%$ and high FIGO stage were associated with high levels of GDF-15 in plasma ( $P=0.04$ and $P=0.03$, respectively). Amplification of $6 \mathrm{p} 21$ was associated with higher GDF15 concentration in plasma $(P=0.045$, Mann Whitney $\mathrm{U}$-test). Although the sample set is too small to draw definitive negative conclusions, no other clear associations were found, in particular not between these angiogenic factors and tissue based angiogenesis markers.

\section{DISCUSSION}

Tumor-vascular interactions have been increasingly focused as important driver mechanisms in malignant tumors [32,33]. In particular, angiogenesis is considered a major hallmark and important for the growth and spread of cancers [34,35], also representing a therapeutic target [36]. Regarding endometrial cancer, we previously reported that active angiogenesis and vascular invasion by tumor cells were related events and important for disease progress in these patients [4,5]. Here, we confirm in two independent series of endometrial cancer that active angiogenesis, using the novel tissue-based marker microvessel proliferation (MVP), is significantly related to aggressive endometrial cancer.

Gene expression signatures may have a stronger potential to reflect the complexity of cancer biology as compared to the detection of single gene or protein alterations, and thereby be relevant as prognostic and predictive cancer biomarkers. Thus, gene expression signatures are suggested to be of value for improved molecular classification and identification of high-grade subgroups, as published in specific cancer types [3739], and also recently demonstrated for endometrial carcinomas $[7,26,40]$. Two gene expression signatures (MammaPrint and Oncotype Dx) are approved for clinical utility in breast cancer, predicting risk of recurrence and metastatic disease, and utilized to direct adjuvant therapy to high-risk cases [41].

In our study, a 32-gene angiogenesis signature was found to reflect tumors with high microvessel proliferation, and the corresponding signature score was associated with aggressive tumorfeatures and reduced survival, also validated in two independent data sets. Whereas several genes in the signature are previously associated with vascular biology $[19,20,42]$, multiple genes have not been previously linked to angiogenesis. Notably, the genes NFIL3, FSTL3 and FHL3 are up-regulated with highest fold-change in tumors with high vascular proliferation, and these are not directly linked to angiogenesis. NFIL3 is suggested to take part in inhibition of apoptosis [43], potentially also in vasculature, and this mechanism may suggest a link between NFIL3 and angiogenesis. NFIL3 is overexpressed in several cancer types, and is associated with reduced survival in breast cancer [44]. In a mouse model of atherosclerosis, FHL3 was demonstrated to have anti-apoptotic effects in endothelial cells, through upregulation of Bcl-2 via the PI3K pathway [45]. FSTL3, another gene up-regulated in tumors with high vascular proliferation, is suggested to promote endothelial cell proliferation [46]. Among down-regulated genes in cases with high vascular proliferation, only few of these are previously associated with cancer. The gene $F U K$ is reported to be down-regulated in specialized stem cells (side population cells) and associated with chemoresistance in malignant melanoma [47]. The genes FHIT and RBM5 are suggested as tumor suppressor genes $[21,47]$. Taken together, mechanisms for how genes in the 32-gene signature might influence angiogenesis in cancer needs to be further explored $[21,47]$.

The 32-gene score was related to predefined and prognostic gene sets reflecting VEGF activity, wound response, endothelial cell gene expression, epithelialmesenchymal transition, and a BMI-1 based stemness signature. These findings support a biological relevance of the 32-gene signature, and indicate that tumor angiogenesis is an important feature of aggressive endometrial cancer and should be considered for targeted treatment.

Interestingly, a subset of the cases (15\%) showed evidence of 6 p21 amplification, which was a strong predictor of increased microvessel proliferation and VEGF-A mRNA expression. VEGF-A is considered an important angiogenic growth factor and is located in the 6 p21 chromosomal region [48], although there are some conflicting results about the association between copy number of $6 \mathrm{p} 21$ and VEGF expression [49,50]. In our study, 6p21 amplification was significantly associated with aggressive features of endometrial carcinomas and reduced patient survival. Of note, amplification of $6 \mathrm{p} 21$ was also associated with increased serum-concentration of GDF-15, which has been considered an angiogenic factor.

Taken together, our results suggest that increased microvessel proliferation in endometrial cancer is reflected by a 32-gene expression signature which includes several genes possibly related to angiogenesis. Also, 6p21 amplification is a potential driver of angiogenesis in a subset of the tumors, and our findings propose further studies of VEGF amplification as a biomarker for response to anti-angiogenic therapy. This is in line with recent publications on possible targets for treating endometrial carcinoma $[2,51]$. 


\section{MATERIALS AND METHODS}

\section{Patient series}

A primary investigation series $(\mathrm{n}=77)$ and an independent validation series $(n=37)$ of endometrial carcinomas (primary tumors) were prospectively enrolled during 2001-2004 and 2009-2011, respectively, as part of a population-based tissue bank. Clinico-pathologic data such as age at time of diagnosis, treatment modality, histologic type and histologic grade, blood vessel invasion, lymphatic vessel invasion, myometrial infiltration, FIGO stage (2009) and disease specific and overall survival were recorded. All samples were reviewed and characterized by one pathologist (I.M.S.) according to published criteria [4]. For the validation series, functional MRI data reflecting tumor blood flow was included, as previously reported [31] Further details on the patient series are given in earlier publications [31,52].

A publicly available gene expression microarray data set of 111 endometrial carcinomas was obtained from the Expression Project for Oncology (expO:http//expo. intgen.org/geo/home.do. GSE 2109 expO) and applied for validation. GEO accession numbers and clinico-pathologic details on this series are previously described [52].

\section{Immunohistochemistry}

Standard $5 \mu \mathrm{m}$ sections of formalin-fixed and paraffin-embedded tumor tissues were used. Vascular proliferation was determined as described, using dual staining for Factor-VIII/Ki-67. Briefly, for antigen retrieval, slides were boiled for $20 \mathrm{~min}$ in Tris EDTA buffer, PH 9. The slides were incubated in 60 minutes at room temperature with monoclonal antibody $\mathrm{Ki}-67$ / MIB-1 (DAKO Norway, Oslo) 1:200, and Factor-VIII polyclonal rabbit antibody (DAKO) 1:800. Ki-67 staining was detected by a biotinylated goat anti mouse secondary antibody 1:100 (E0433, DAKO), and a streptavidin ABcomplex (K0391, DAKO) with Fast Blue as chromogen, while Factor-VIII was detected by EV rabbit HRP secondary antibody 1:50, and AEC-peroxidase as a substrate Slides from 75 cases were available and of sufficient quality and quantity for this marker. Staining for ER and PR was performed as previously described [53].

For detection of Glomeruloid Microvascular Proliferations (GMP)[15], slides were treated with proteolytic enzyme (antigen retrieval) in $5 \mathrm{~min}$, followed by incubation with polyclonal Factor-VIII Ab 1:800 in 60 minutes. Staining was done by the rabbit EnVision Kit (DAKO) with diaminobenzidine peroxidase (DAB, DAKO) as substrate. Finally, the sections were counterstained with Dako REAL haematoxylin for 2 minutes. Slides from 76 cases were available for this marker.

\section{Evaluation of staining results}

Microvessel density (MVD) was recorded as previously described [5]. Regarding the novel angiogenesis marker microvascular proliferation (MVP), dividing endothelial cells were recognized by their morphology, their localization, and by distinct Factor-VIII/Ki-67 coexpression. Positive nuclei outside the endothelial cell layer, or within the vessel lumen, were avoided. Vascular proliferation index (VPI) was determined by calculating the ratio between the number of microvessels with proliferating endothelial cells, divided by the total number of Factor-VIII positive microvessels (\%), as examined within "hot-spot" areas [5].

Glomeruloid Microvascular Proliferation (GMP) [16] was included because of its prognostic impact found in recent studies of various human cancers [15,54-56]. Presence of GMP was recorded as described [15] and categorized as being present or absent.

\section{Oligonucleotide DNA microarray analyses}

Fresh tumor tissues were immediately frozen in liquid nitrogen and stored at $-80^{\circ} \mathrm{C}$. Extracted RNA was hybridized to Agilent Whole Human Genome Microarrays 44k (Cat.no. G4112F), according to manufacturer's instructions (www.agilent.com). Arrays were scanned using the Agilent Microarray Scanner Bundle. Microarray signal intensities were determined using J-Express (www.molmine.no). Median spot signal data were used as intensity measure. The expression data were quantile normalized.

Genes differentially expressed between high and low microvessel proliferation (MVP; by median value) were identified by Significance Analysis of Microarray (SAM) [57]. Gene sets differentially enriched between high and low vascular proliferations were explored by Gene set enrichment analysis (GSEA) [58], based on gene sets available through MSigDB (www.broadinstitute.org/ gsea/msigdb).

\section{Gene expression signatures}

Gene expression signature scores were calculated for a 32-gene vascular proliferation signature (see Results) and for a VEGF signature [25], a vascular invasion signature [26], a wound response signature [27], a hypoxia gene signature [28], a TGF $\beta$ gene-response signature of human epithelial cells [29] and a BMI-1 driven stemness related gene signature [30]. All expression values were normalized to a common mean and scaled to the same standard deviation before included in the signature score 
[59]. The 32-gene angiogenesis score was calculated by subtracting the sum of expression values of genes with a low expression from the sum of expression values of genes with high expression in cases with high vascular proliferation. Signature scores were calculated in the same manner for the vascular invasion signature, the hypoxia gene signature, the TGF- $\beta$ response signature, and the BMI-1 driven gene signature. Mean expression of all genes in the VEGF signature and the wound response signature (the activated genes) constituted the scores for these signatures. For the wound response signature, two out of 208 genes were not found, and three of 153 genes were not found in the TGF- $\beta$ signature.

\section{Genomic copy number assessment}

Genomic DNA was analyzed for copy number alterations by SNP arrays interrogating 116,204 SNP loci (Affymetrix) and the GISTIC algorithm, as previously described $[7,60]$.

\section{Serum markers of angiogenesis}

In a subset of 44 endometrial cancer patients, blood samples were analyzed for several angiogenic factors prior to hysterectomy. Details on this patient population are previously published [61]. The following markers were analyzed in serum: VEGF-A, PIGF, GDF-15, sFlt, and sEng [61-63]. Briefly, after 30-60 min at room temperature, serum was obtained by centrifugation and stored at $-80^{\circ} \mathrm{C}$ until assay. Serum concentrations were determined by ELISA (enzyme-linked immunosorbent assay) for human VEGF-A, human PlGF, human sEng and human sFlt1 according to the manufacturer's instructions (R\&D systems, Minneapolis, MN). The VEGF and PlGF assays detect free, but not bound, forms of the growth factors. GDF-15 detected in plasma was measured by an immunoradiometric sandwich assay as previously published [61]. The assays were done in duplicate and the results are given in $\mathrm{pg} / \mathrm{mL}$ serum $[62,63]$.

\section{Statistical methods}

Comparisons of groups were performed by Pearson's $\mathrm{x}^{2}$ test. Mann-Whitney U test was applied for comparison of continuous variables between categories. Spearman correlation coefficient was reported for bivariate correlation between continuous variables. Univariate survival analyses were performed using the productlimit procedure (Kaplan-Meier method), with time of primary surgery as the entry date. Death from endometrial carcinoma or recurrent and progressive disease were applied as end points; death from other causes and no recurrence or progression were censored, respectively. The log-rank (Mantel-Cox) test was used to compare survival curves for different categories of each variable.

\section{ACKNOWLEGDEMENTS}

We thank Gerd Lillian Hallseth, Bendik Nordanger and Britt Edvardsen for excellent technical help. L.A.A. is supported by grants from The Research Council of Norway, The Norwegian Cancer Society, and Helse Vest Research Fund.

This work was partly supported by the Research Council of Norway through its Centres of Excellence funding scheme, project number 223250.

\section{REFERENCES}

1. Salvesen HB, Haldorsen IS, Trovik J. Markers for individualised therapy in endometrial carcinoma. The lancet oncology 2012;13:e353-361.

2. Dedes KJ, Wetterskog D, Ashworth A, Kaye SB, Reis-Filho JS. Emerging therapeutic targets in endometrial cancer. Nature reviews Clinical oncology 2011;8:261-271.

3. Felix AS, Weissfeld J, Edwards R, Linkov F. Future directions in the field of endometrial cancer research: the need to investigate the tumor microenvironment. European journal of gynaecological oncology 2010;31:139-144.

4. Stefansson IM, Salvesen HB, Immervoll H, Akslen LA. Prognostic impact of histological grade and vascular invasion compared with tumour cell proliferation in endometrial carcinoma of endometrioid type. Histopathology 2004;44:472-479.

5. Stefansson IM, Salvesen HB, Akslen LA. Vascular proliferation is important for clinical progress of endometrial cancer. Cancer Res 2006;66:3303-3309.

6. Mannelqvist M, Stefansson I, Salvesen HB, Akslen LA. Importance of tumour cell invasion in blood and lymphatic vasculature among patients with endometrial carcinoma. Histopathology 2009;54:174-183.

7. Salvesen HB, Carter SL, Mannelqvist M, Dutt A, Getz G, Stefansson IM, Raeder MB, Sos ML, Engelsen IB, Trovik J, Wik E, Greulich H, Bo TH, et al. Integrated genomic profiling of endometrial carcinoma associates aggressive tumors with indicators of PI3 kinase activation. Proceedings of the National Academy of Sciences of the United States of America 2009;106:4834-4839.

8. Mannelqvist M, Stefansson IM, Wik E, Kusonmano K, Raeder MB, Oyan AM, Kalland KH, Moses MA, Salvesen $\mathrm{HB}$, Akslen LA. Lipocalin 2 expression is associated with aggressive features of endometrial cancer. BMC cancer 2012;12:169.

9. Arnes JB, Stefansson IM, Straume O, Baak JP, Lonning PE, Foulkes WD, Akslen LA. Vascular proliferation is a prognostic factor in breast cancer. Breast cancer research and treatment 2012;133:501-510. 
10. Kruger K, Stefansson IM, Collett K, Arnes JB, Aas T, Akslen LA. Microvessel proliferation by co-expression of endothelial nestin and Ki-67 is associated with a basal-like phenotype and aggressive features in breast cancer. Breast 2013;22:282-288.

11. Nalwoga H, Arnes JB, Stefansson IM, Wabinga H, Foulkes WD, Akslen LA. Vascular proliferation is increased in basal-like breast cancer. Breast cancer research and treatment 2011;130:1063-1071.

12. Stefansson IM, Salvesen HB, Akslen LA. Prognostic impact of alterations in P-cadherin expression and related cell adhesion markers in endometrial cancer. Journal of clinical oncology : official journal of the American Society of Clinical Oncology 2004;22:1242-1252.

13. McConechy MK, Ding J, Cheang MC, Wiegand $\mathrm{KC}$, Senz J, Tone AA, Yang W, Prentice LM, Tse K, Zeng T, McDonald H, Schmidt AP, Mutch DG, et al. Use of mutation profiles to refine the classification of endometrial carcinomas. The Journal of pathology 2012;228:20-30.

14. Cancer Genome Atlas Research N, Kandoth C, Schultz N, Cherniack AD, Akbani R, Liu Y, Shen H, Robertson AG, Pashtan I, Shen R, Benz CC, Yau C, Laird PW, et al. Integrated genomic characterization of endometrial carcinoma. Nature 2013;497:67-73.

15. Straume O, Chappuis PO, Salvesen HB, Halvorsen OJ, Haukaas SA, Goffin JR, Begin LR, Foulkes WD, Akslen LA. Prognostic importance of glomeruloid microvascular proliferation indicates an aggressive angiogenic phenotype in human cancers. Cancer Res 2002;62:6808-6811.

16. Sundberg C, Nagy JA, Brown LF, Feng D, Eckelhoefer IA, Manseau EJ, Dvorak AM, Dvorak HF. Glomeruloid microvascular proliferation follows adenoviral vascular permeability factor/vascular endothelial growth factor-164 gene delivery. The American journal of pathology 2001;158:1145-1160.

17. Weigand JE, Boeckel JN, Gellert P, Dimmeler S. Hypoxiainduced alternative splicing in endothelial cells. PloS one 2012; 7:e42697.

18. Carmeliet P. Mechanisms of angiogenesis and arteriogenesis. Nature medicine 2000;6:389-395.

19. Mustafa D, van der Weiden M, Zheng P, Nigg A, Luider TM, Kros JM. Expression sites of colligin 2 in glioma blood vessels. Brain pathology 2010;20:50-65.

20. Hayashi H, Sano H, Seo S, Kume T. The Foxc2 transcription factor regulates angiogenesis via induction of integrin beta3 expression. The Journal of biological chemistry 2008;283:23791-23800.

21. Verrecchia F, Chu ML, Mauviel A. Identification of novel TGF-beta /Smad gene targets in dermal fibroblasts using a combined cDNA microarray/promoter transactivation approach. The Journal of biological chemistry 2001;276:17058-17062.

22. Lu C, Bonome T, Li Y, Kamat AA, Han LY, Schmandt R, Coleman RL, Gershenson DM, Jaffe RB, Birrer MJ, Sood
AK. Gene alterations identified by expression profiling in tumor-associated endothelial cells from invasive ovarian carcinoma. Cancer Res 2007;67:1757-1768.

23. Hillion J, Dhara S, Sumter TF, Mukherjee M, Di Cello F, Belton A, Turkson J, Jaganathan S, Cheng L, Ye Z, Jove R, Aplan P, Lin YW, et al. The high-mobility group A1a/ signal transducer and activator of transcription-3 axis: an achilles heel for hematopoietic malignancies? Cancer Res 2008;68:10121-10127.

24. Pang B, Fan H, Zhang IY, Liu B, Feng B, Meng L, Zhang R, Sadeghi S, Guo H, Pang Q. HMGA1 expression in human gliomas and its correlation with tumor proliferation, invasion and angiogenesis. Journal of neuro-oncology 2012;106:543-549.

25. Hu Z, Fan C, Livasy C, He X, Oh DS, Ewend MG, Carey LA, Subramanian S, West R, Ikpatt F, Olopade OI, van de Rijn M, Perou CM. A compact VEGF signature associated with distant metastases and poor outcomes. BMC medicine 2009;7:9.

26. Mannelqvist M, Stefansson IM, Bredholt G, Hellem Bo T, Oyan AM, Jonassen I, Kalland KH, Salvesen HB, Akslen LA. Gene expression patterns related to vascular invasion and aggressive features in endometrial cancer. The American journal of pathology 2011;178:861-871.

27. Chang HY, Sneddon JB, Alizadeh AA, Sood R, West RB, Montgomery K, Chi JT, van de Rijn M, Botstein D, Brown PO. Gene expression signature of fibroblast serum response predicts human cancer progression: similarities between tumors and wounds. PLoS biology 2004;2:E7.

28. Chi JT, Wang Z, Nuyten DS, Rodriguez EH, Schaner ME, Salim A, Wang Y, Kristensen GB, Helland A, BorresenDale AL, Giaccia A, Longaker MT, Hastie T, et al. Gene expression programs in response to hypoxia: cell type specificity and prognostic significance in human cancers. PLoS medicine 2006;3:e47.

29. Padua D, Zhang XH, Wang Q, Nadal C, Gerald WL, Gomis RR, Massague J. TGFbeta primes breast tumors for lung metastasis seeding through angiopoietin-like 4. Cell 2008;133:66-77.

30. Glinsky GV, Berezovska O, Glinskii AB. Microarray analysis identifies a death-from-cancer signature predicting therapy failure in patients with multiple types of cancer. The Journal of clinical investigation 2005;115:1503-1521.

31. Haldorsen IS, Stefansson I, Gruner R, Husby JA, Magnussen IJ, Werner HM, Salvesen OO, Bjorge L, Trovik J, Taxt $\mathrm{T}$, Akslen LA, Salvesen HB. Increased microvascular proliferation is negatively correlated to tumour blood flow and is associated with unfavourable outcome in endometrial carcinomas. Br J Cancer 2014;110:107-114.

32. Witkiewicz AK, Casimiro MC, Dasgupta A, Mercier I, Wang C, Bonuccelli G, Jasmin JF, Frank PG, Pestell RG, Kleer CG, Sotgia F, Lisanti MP. Towards a new "stromalbased" classification system for human breast cancer prognosis and therapy. Cell Cycle 2009;8:1654-1658. 
33. Wysoczynski M, Ratajczak MZ. Lung cancer secreted microvesicles: underappreciated modulators of microenvironment in expanding tumors. Int $\mathrm{J}$ Cancer 2009; 125:1595-1603.

34. Hanahan D, Weinberg RA. Hallmarks of cancer: the next generation. Cell 2011;144:646-674.

35. Potente M, Gerhardt H, Carmeliet P. Basic and therapeutic aspects of angiogenesis. Cell 2011;146:873-887.

36. Claesson-Welsh L. Blood vessels as targets in tumor therapy. Upsala journal of medical sciences 2012;117:178186.

37. Dancik GM, Theodorescu D. Robust prognostic gene expression signatures in bladder cancer and lung adenocarcinoma depend on cell cycle related genes. PloS one 2014;9:e85249.

38. Ma CX, Ellis MJ. The Cancer Genome Atlas: clinical applications for breast cancer. Oncology 2013;27:12631269, 1274-1269.

39. Sanz-Pamplona R, Berenguer A, Cordero D, Riccadonna S, Sole X, Crous-Bou M, Guino E, Sanjuan X, Biondo S, Soriano A, Jurman G, Capella G, Furlanello C, et al. Clinical value of prognosis gene expression signatures in colorectal cancer: a systematic review. PloS one 2012;7:e48877.

40. Engelsen IB, Mannelqvist M, Stefansson IM, Carter SL, Beroukhim R, Oyan AM, Otte AP, Kalland KH, Akslen LA, Salvesen HB. Low BMI-1 expression is associated with an activated BMI-1-driven signature, vascular invasion, and hormone receptor loss in endometrial carcinoma. Br J Cancer 2008;98:1662-1669.

41. Harbeck N, Sotlar K, Wuerstlein R, Doisneau-Sixou S. Molecular and protein markers for clinical decision making in breast cancer: today and tomorrow. Cancer treatment reviews 2014;40:434-444

42. Schito L, Rey S, Tafani M, Zhang H, Wong CC, Russo A, Russo MA, Semenza GL. Hypoxia-inducible factor 1-dependent expression of platelet-derived growth factor B promotes lymphatic metastasis of hypoxic breast cancer cells. Proceedings of the National Academy of Sciences of the United States of America 2012;109:E2707-2716.

43. Iida K, Koseki H, Kakinuma H, Kato N, Mizutani-Koseki Y, Ohuchi H, Yoshioka H, Noji S, Kawamura K, Kataoka Y, Ueno F, Taniguchi M, Yoshida N, et al. Essential roles of the winged helix transcription factor MFH-1 in aortic arch patterning and skeletogenesis. Development 1997; 124:4627-4638.

44. Nishimura Y, Tanaka T. Calcium-dependent activation of nuclear factor regulated by interleukin 3/adenovirus E4 promoter-binding protein gene expression by calcineurin/ nuclear factor of activated $\mathrm{T}$ cells and calcium/calmodulindependent protein kinase signaling. The Journal of biological chemistry 2001;276:19921-19928.

45. Liu S, Shen H, Xu M, Liu O, Zhao L, Liu S, Guo Z, Du J. FRP inhibits ox-LDL-induced endothelial cell apoptosis through an Akt-NF-\{kappa\}B-Bcl-2 pathway and inhibits endothelial cell apoptosis in an apoE-knockout mouse model. American journal of physiology Endocrinology and metabolism 2010;299:E351-363.

46. Shen H, Liu YY. [Pathophysiological functions of follistatin related protein]. Sheng li ke xue jin zhan [Progress in physiology] 2009;40:313-316.

47. Luo Y, Ellis LZ, Dallaglio K, Takeda M, Robinson WA, Robinson SE, Liu W, Lewis KD, McCarter MD, Gonzalez R, Norris DA, Roop DR, Spritz RA, et al. Side population cells from human melanoma tumors reveal diverse mechanisms for chemoresistance. The Journal of investigative dermatology 2012;132:2440-2450.

48. Vincenti V, Cassano C, Rocchi M, Persico G. Assignment of the vascular endothelial growth factor gene to human chromosome 6p21.3. Circulation 1996;93:1493-1495.

49. Abdel-Rahman MH, Craig EL, Davidorf FH, Eng C. Expression of vascular endothelial growth factor in uveal melanoma is independent of 6p21-region copy number. Clin Cancer Res 2005;11:73-78.

50. Yang J, Yang D, Sun Y, Sun B, Wang G, Trent JC, Araujo DM, Chen K, Zhang W. Genetic amplification of the vascular endothelial growth factor (VEGF) pathway genes, including VEGFA, in human osteosarcoma. Cancer 2011;117:4925-4938.

51. Bansal N, Yendluri V, Wenham RM. The molecular biology of endometrial cancers and the implications for pathogenesis, classification, and targeted therapies. Cancer control : journal of the Moffitt Cancer Center 2009;16:8-13.

52. Wik E, Raeder MB, Krakstad C, Trovik J, Birkeland E, Hoivik EA, Mjos S, Werner HM, Mannelqvist M, Stefansson IM, Oyan AM, Kalland KH, Akslen LA, et al. Lack of estrogen receptor-alpha is associated with epithelial-mesenchymal transition and PI3K alterations in endometrial carcinoma. Clin Cancer Res 2013;19:10941105 .

53. Engelsen IB, Stefansson IM, Akslen LA, Salvesen HB. GATA3 expression in estrogen receptor alpha-negative endometrial carcinomas identifies aggressive tumors with high proliferation and poor patient survival. Am J Obstet Gynecol 2008;199:543 e541-547.

54. Peddinti R, Zeine R, Luca D, Seshadri R, Chlenski A, Cole K, Pawel B, Salwen HR, Maris JM, Cohn SL. Prominent microvascular proliferation in clinically aggressive neuroblastoma. Clin Cancer Res 2007;13:3499-3506.

55. Goffin JR, Straume O, Chappuis PO, Brunet JS, Begin LR, Hamel N, Wong N, Akslen LA, Foulkes WD. Glomeruloid microvascular proliferation is associated with p53 expression, germline BRCA1 mutations and an adverse outcome following breast cancer. Br J Cancer 2003;89:1031-1034.

56. Hoem D, Straume O, Immervoll H, Akslen LA, Molven A. Vascular proliferation is associated with survival in pancreatic ductal adenocarcinoma. APMIS : acta 
pathologica, microbiologica, et immunologica Scandinavica 2013;121:1037-1046.

57. Tusher VG, Tibshirani R, Chu G. Significance analysis of microarrays applied to the ionizing radiation response. Proceedings of the National Academy of Sciences of the United States of America 2001;98:5116-5121.

58. Subramanian A, Tamayo P, Mootha VK, Mukherjee S, Ebert BL, Gillette MA, Paulovich A, Pomeroy SL, Golub TR, Lander ES, Mesirov JP. Gene set enrichment analysis: a knowledge-based approach for interpreting genomewide expression profiles. Proceedings of the National Academy of Sciences of the United States of America 2005; 102:15545-15550.

59. Huang E, Ishida S, Pittman J, Dressman H, Bild A, Kloos M, D'Amico M, Pestell RG, West M, Nevins JR. Gene expression phenotypic models that predict the activity of oncogenic pathways. Nature genetics 2003;34:226-230.

60. Beroukhim R, Getz G, Nghiemphu L, Barretina J, Hsueh T, Linhart D, Vivanco I, Lee JC, Huang JH, Alexander S, Du J, Kau T, Thomas RK, et al. Assessing the significance of chromosomal aberrations in cancer: methodology and application to glioma. Proceedings of the National Academy of Sciences of the United States of America 2007; 104:20007-20012.

61. Staff AC, Trovik J, Eriksson AG, Wik E, Wollert KC, Kempf T, Salvesen HB. Elevated plasma growth differentiation factor-15 correlates with lymph node metastases and poor survival in endometrial cancer. Clin Cancer Res 2011;17:4825-4833.

62. Troisi R, Braekke K, Harsem NK, Hyer M, Hoover RN, Staff AC. Blood pressure augmentation and maternal circulating concentrations of angiogenic factors at delivery in preeclamptic and uncomplicated pregnancies. Am J Obstet Gynecol 2008;199:653 e651-610.

63. Staff AC, Braekke K, Johnsen GM, Karumanchi SA, Harsem NK. Circulating concentrations of soluble endoglin (CD105) in fetal and maternal serum and in amniotic fluid in preeclampsia. Am J Obstet Gynecol 2007;197:176 e171176. 